Rapp. Grønlands geol. Unders. 48, 7-20 (1972)

\title{
PRELIMINARY RESULTS OF MAPPING IN LIVERPOOL LAND, EAST GREENLAND
}

\author{
K. Coe and R. F. Cheeney
}

\section{Introduction and previous work}

The Geological Survey of Greenland (GGU) began mapping in Liverpool Land in 1969 with two geologists, operating mostly from coast camps in Hurry Inlet. The basic survey on the scale of 1:50000 was completed by five teams in 1971. The inset to the map (map 1) shows the division of responsibility for the areas mapped.

Previous work in the area was of variable assistance. Observations by Nathorst (1901) and Nordenskjöld (1907) were superficial, but Kranck's general survey (1935) proved very valuable. Kleiber (1944) reported accurately on coast traverses in the northern and north-western parts and Bütler (1957), using a more modern approach, made a valuable contribution, but restricted himself to the younger, non-metamorphosed sediments.

In compiling the map to the scale 1:500 000 inevitable generalisations have been made and in some cases simplification has concealed significant problems. In the description that follows, attempts have been made to maintain consistency with the map but in places there are references to the problems and complexities. Further statements will be made in later reports. This report has been compiled jointly making free use of maps and reports provided by all the members of the team.

Liverpool Land consists of a strongly deformed crystalline basement, comprising gneisses, marbles and other metasedimentary rocks and granitic and amphibolitic rocks of igneous origin. A series of granitic rocks is very abundantly developed and ranges in temporal position from pre- to post-kinematic, and in composition from granite sensu stricto to diorite. The relations of the series of granitic rocks to the deformation are complicated but a programme of isotope work is currently planned. At the present time the only available isotopic date is $434 \pm 10 \mathrm{~m}$. y. (Hansen \& Steiger, 1971) for a late phase of one of the post-kinematic granites, so that no definite statement on the span of time involved in the overall development can be made. The problem is discussed below.

Post-crystalline rocks are of three categories; a sequence of non-metamorphosed clastic rocks clearly derived principally from the breakdown of the granites, and believed to be Upper Palaeozoic in age; sediments of Mesozoic age which correlate 
Fig. 1. Key map indicating the location of nine sketch maps (maps $1-4$ and figs 5, 11-13 \& 15) which accompany this report. The key map also serves as a general geographical reference map

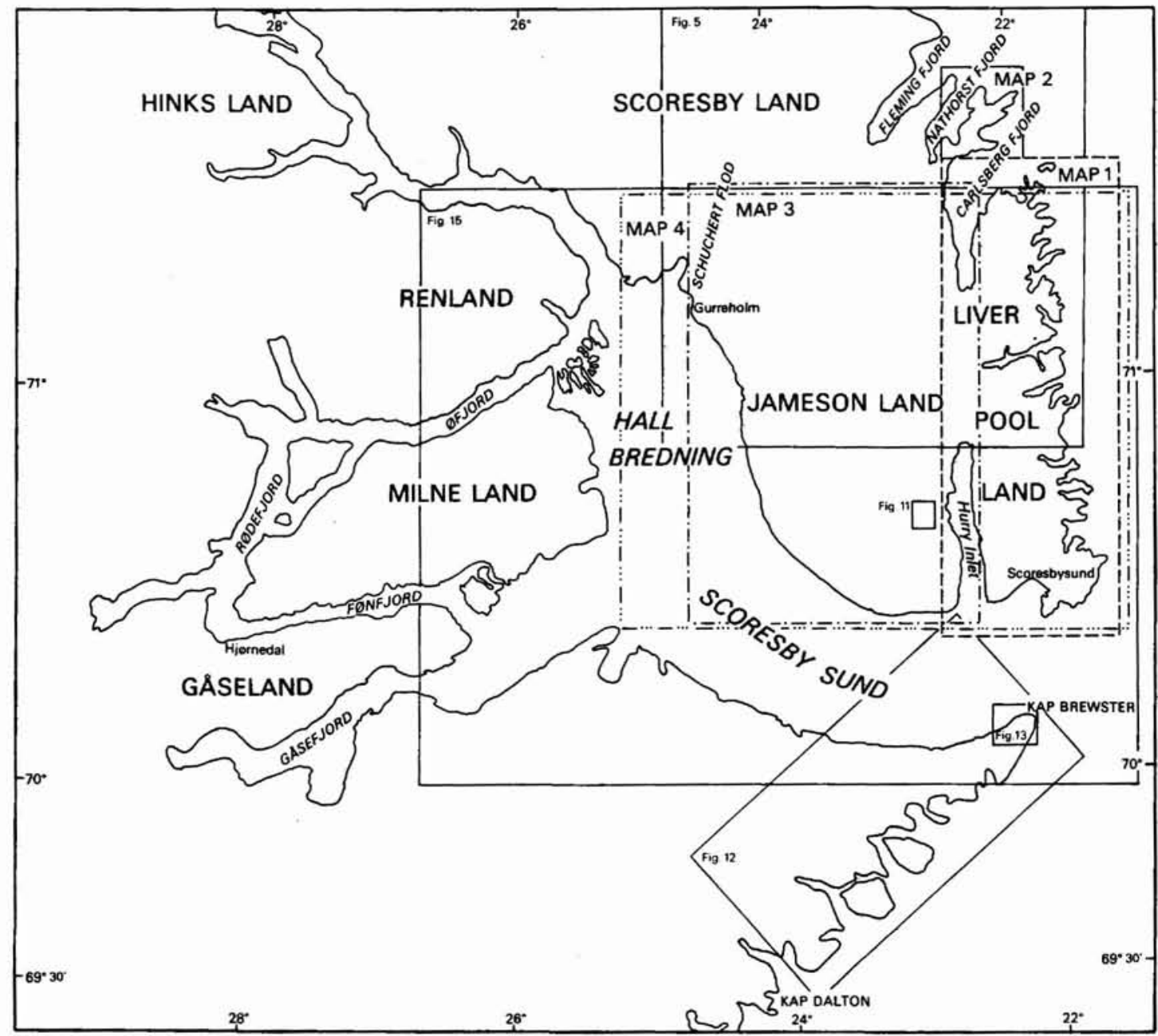


with strata of Jameson Land (Surlyk \& Birkelund, this report); and dykes of lamprophyric and basaltic aspect which are Tertiary in age.

\section{Metamorphic rocks}

The term gneiss has been widely used in a somewhat loose fashion for the metamorphic rocks of Liverpool Land. It will be seen that most of these are perhaps of sedimentary parentage although minor intrusions and possibly lavas also contributed. The metamorphic rocks occur in three areas, each being characterised by a particular assemblage of lithologies.

\section{South Liverpool Land}

In this area four subdivisions have been established. These are, in descending structural order:

Granodioritic sensu lato gneiss

Metasedimentary groups

Veined garnet-hornblende-biotite gneiss

Metasedimentary hornblende gneiss

The metasedimentary hornblende gneiss

These form a small outcrop near Kap Hodgson where a total thickness of about 700 $\mathrm{m}$ is exposed. A marked colour banding is the most prominent feature of the group, individual layers being up to a few metres thick. Hornblendic gneisses make up most of the succession but there are abundant bands of both pink and white marble. Some black amphibolite sheets, only a few centimetres thick, are slightly discordant to the main banding of the gneisses. A few of these sheets contain xenolithic inclusions. The presence of these sheets especially, but the overall characters of the whole group, invite comparison with the gneisses of Kap Greg as described by Kranck (1935, p. 49), and discussed below (p. 11).

\section{The veined garnet-hornblende-biotite gneiss}

This group crops out over a large area in south Liverpool Land. Its characters vary within the area of outcrop, but there are no rapid lateral variations. Its lower contact, with the metasedimentary hornblende gneisses, is transitional over a few tens of metres. The principal rock types are gneisses with varying amounts of mafic minerals ranging from a very small to a very large proportion of the whole rock. In the west, near Hurry Inlet, these gneisses are commonly garnetiferous and some layers are composed entirely of this mineral. The western exposures frequently contain inclusions of basic or ultrabasic gneiss. These may be rounded or angular, but their most prominent structural feature is that they contain a mineral banding 
which is oblique to the banding in the host gneisses. The inclusions are mostly garnet pyroxenites and almost pure garnet rocks. Kranck (1935) and Sahlstein (1935) referred to some of them as 'eclogites' but is is doubtful if this term can be applied in the sense of its current usage. The whole complex of host gneisses and inclusions is cut across by irregular veins containing garnet and hornblende.

Thin sections of the inclusions show a clear transformation of the pyroxene to newer hornblende and this, coupled with the disorientated banding of the inclusions, indicates that an older metamorphic complex has been broken up and partially or completely reconstituted into the present gneiss group. North of the Mesozoic outcrop lying north-east of Kap Hope, there are a few inclusions of dunite and peridotite. Farther east the characters of the group change somewhat; although inclusions are still present, they are all rounded and contain hornblende as the only ferromagnesian mineral. Pegmatites free of ferromagnesian minerals are found; some of them have been boudinaged. There are also discordant amphibolite sheets. A mineral-elongation lineation becomes more prominent towards the east.

In the north-east, 5 to $10 \mathrm{~km}$ south of Lillefjord, this gneiss group contains feldspar augen, some of which are contained in a schistose base. Nearer to Lillefjord, the group shows a lateral transition into foliated granodiorite and there can be little doubt that some of the gneiss, at least, has been developed from the east coast granodiorites by a process of intense deformation. From Hurry Inlet to the east coast, the northern margin of this group seems to be enveloped by a strongly lineated, fine-grained hornblende schist, often of mylonitic aspect, making a layer about $\mathbf{2 0 0}$ metres thick. Only in the east is there evidence for the origin of this rock, where a lateral transition into an ultramafic, hornblende-pyroxenite associate of the granodiorite body is seen.

\section{The metasedimentary group}

Garnetiferous acid gneisses, marbles (with or without skarn minerals), garnetiferous amphibolites, quartzites and kyanite schists form a mixed, layered sequence 200 to $1000 \mathrm{~m}$ thick. In the east, a large intercalation of the granodioritic sensu lato gneiss has split the metasedimentary group into two tongues. The lower contact of the group, with the veined garnet-hornblende-biotite gneiss, is fairly sharp.

\section{The granodioritic sensu lato gneiss}

This coarse-grained hornblende-biotite gneiss group contains large feldspar porphyroblasts in some layers and also layers of concordant amphibolite, mostly agmatised. There are a few discordant basic sheets also composed of amphibolite. All of these rock types are cut by abundant aplites and pegmatites.

Like the eastern outcrops of the veined garnet-hornblende-biotite gneiss group, this group can also be followed through a transition into the foliated variants of the east coast granodiorite. Indeed, a remnant of the granodiorite can be found within 
the granodioritic gneiss about $12 \mathrm{~km}$ west of Lillefjord. Much of the feldspar of the gneiss is plagioclase.

\section{Structures}

Foliation dips are low and generally northwards. Consequently the lowest structural group crops out in the extreme south. The metamorphic layering is disposed in broad basin and swell flexures so that there are only a few large folds and these are so open that their crestal traces cannot be easily followed.

A lineation in the rocks, defined by an elongate shape of the constituent grains, trends more or less north-south and can be associated with the strong deformation of some earlier pegmatites and discordant basic sheets. The same deformation event probably induced the foliation in parts of the granodiorite mass on the east coast and caused its partial transformation to gneiss.

\section{East central Liverpool Land}

The northern part of east central Liverpool Land consists of a sequence of gneisses, the Kap Greg gneisses of Kranck (1935). These extend to Mariager Fjord where they are cut off by an important thrust. In the southern part they are overlain by discontinuous amphibolitic rocks, marbles and a prominent siliceous garnet gneiss. The Kap Greg gneisses are mostly granitic in composition but have psammitic and calcareous horizons and amphibolite sheets. The sequence is exposed in a broad dome with the major axial trace trending $075^{\circ}$ through Kap Greg; this simple structure tends to conceal complexities which must have predated its formation.

A lower division with limited outcrop can be recognised in the core of the main structure in the vicinity of Kap Greg. Most of the lower series comprises a grey granitic gneiss, probably orthogneiss, foliated but not always banded. The foliation, and a lineation formed by streaked out feldspars, are at variance with the main dome structure of the region. Locally interference structures with eye-folds are seen and the lineation lying oblique to the hinges of minor folds is deformed. The complexity of the structural pattern as compared to the upper series suggests the lower series may be older, and perhaps already in a gneissic condition prior to deposition of the upper series. The junction between the upper and lower series is not always clearly defined, and there has apparently been a tectonic convergence comparable to that which is described between the Krummedal supracrustal rocks and Flyverfjord basement rocks by Henriksen \& Higgins (1969).

No discontinuity can be determined within the upper series. The sequence is $2500 \mathrm{~m}$ thick with calcareous horizons distributed in lenses throughout, showing the sedimentary origin. The main sequence on the southern limb of the dome is of pink and grey granitic gneiss, the pink rocks in the lowest part being frequently augen gneiss. This sequence is succeeded by siliceous bands, almost quartzitic in 
parts, a quartz-mica schist, marble and a very persistent siliceous garnet gneiss. Some of the complexities of the structures in the gneiss are revealed by the relations between amphibolite sheets and host rock. Amphibolite sheets are frequent in occurrence and can be divided into four structural groups:

1) Parallel-sided, thin, concordant sheets.

2) Thin concordant sheets, but boudinaged.

3) Sheets discordant to the foliation and folded.

4) Discordant, parallel-sided sheets.

The structures seen in the second group of sheets vary from minor pinch and swell to boudinage with widely separated lenses, the latter often in the thicker bands which reach up to $15 \mathrm{~m}$ across. Boudinaged and undeformed thin sheets of the same composition in the same exposure suggest perhaps two periods of emplacement separated by deformation, and both succeeded by metamorphism. The folds in the third group are invariably flattened normal to the foliation, and are asymmetric with very high amplitude to wavelength ratio (up to 24:1). The fourth group are the latest in the sequence.

Pegmatite sheets can be similarly divided, some showing boudinage, some folded, and some parallel-sided and discordant. The flattened asymmetric folds are frequent in occurrence and in a considerable majority of cases the long limbs dip to the south.

The flattening is also shown by elongation of feldspars in the augen gneiss, giving the rock a strong lineation. In sample measurements these linear structures, separated into axes of boudins and axes of minor folds, have a common plunge which on the south limb of the dome is parallel to the dip of the foliation. Thus it can be concluded that the domal form is a superficial and late structure, in no way related to the major deformation and with a trend which is oblique to folds measured both to the north and in south Liverpool Land.

\section{North Liverpool Land}

\section{Uniform dark-coloured hornblende-biotite gneiss}

This is a thick monotonous group, relieved only by a few thin marble bands, which crops out only on the peninsulas and islands of north-east Liverpool Land. It is mineralogically uniform, but more massive and leucocratic at lower structural levels (i.e. towards the east) while garnets and amphibolite inclusions become more prominent higher in the sequence.

\section{Slightly migmatitic gneiss and metasediment}

The principal outcrops of this group are in the extreme north of Liverpool Land. It is a varied group showing bright colour banding due to the presence of rusty- 
weathering schists, white, yellow and grey marbles, hornblende gneisses and quartzites. Individual bands up to about $20 \mathrm{~m}$ thick are commonly found and marble zones are several hundreds of metres thick. Sillimanite can be distinguished in some of the schists and skarn minerals are abundant in some of the marbles. Garnet is notably absent. The whole group is invaded by sheets and veins of biotite-garnet and muscovite-tourmaline pegmatites, aplite and biotite granite. Some of the larger granite sheets contain inclusions of the country rocks. The migmatitic development increases in intensity southwards.

\section{Highly migmatitic gneiss with marble bands}

This is the most widespread group in north Liverpool Land. The contact with the group described above is transitional over a distance of several hundreds of metres. The principal rock type is a pale hornblende-biotite gneiss, of granitic composition, with inclusions in irregular bands at intervals in the sequence. Such bands are sparse towards the west. Some of the larger bands of marble inclusions have been distinguished on the map (map 1). Other bands of inclusions contain amphibolite of two compositional types, or more rarely, banded quartzite. The marble inclusions have reaction rims arising from their partial digestion by granitic host rocks. Sharp contacts have not been found between this group and the monzonites and granites to the south and west.

\section{Structures}

Fold structures are much more abundantly developed in the north so that the following structural history can be recognised. First, is the formation of a lineation parallel to the axial directions of small isoclinal folds. The lineation was refolded by a series of small, tight folds. With these second folds can be associated a large reclined fold in a thick marble band at the head of Campbell Sund which has the same axial direction. This is at the site of the limestone anticline of Kranck (1935) but it is doubtful that he was able to view it with the correct perspective and thus determine its true form. A third episode of deformation led to the formation of major flexures which dominate the structure of the area. The flexures are reflected by the dominant strike in three zones, i. e. from west to east: (i) strike north to north-north-east, dip west; (ii) strike west, dip north or south; and (iii) strike north-north-east, dip west. Later than the formation of these structures and postdating the emplacement of the granites there was a period of thrusting. Important low-angled breaks were developed at the head of Mariager Fjord and between there and Storefjord. In that area, the faults carry the gneisses and granites of the northern region on to the Kap Greg gneisses. Of the same style and probably the same age is a thrust north-west of Istorvet which brings together two granite masses. 


\section{Plutonic rocks}

Emplacement of a group of granitic bodies post-dated the formation of the gneiss complexes. Seven groups or types of granites are distinguished, described in this paper according to the classification of Streckeisen (1967). These are:

I) The Åge Nielsen Gletscher granodiorite, which crops out extensively around this glacier and in a belt extending to beyond the head of Horsens Fjord. An inhomogeneous body with ill-defined margins grading into gneiss, it is considered to be the oldest of the series. Parts of it have different relations with the gneisses, especially north and south of Lillefjord, and it is possible that the body comprises more than one phase.

II) The big feldspar granite at Kap Jones. This grades into group V granites.

III) The Sandbach Halvø quartz monzonite. This body continues north almost to Horsens Fjord and is similar to a body of quartz monzonite outcropping east of the northern part of Klitdal.

IV) Hodal-Storefjord quartz monzodiorite, occuring on the west side of Istorvet.

V) Hornblende-biotite granite. This body crops out on the outer coast north and south of Store Fjord, between there and Klitdal, and in a small occurrence flanking Carlsberg Fjord.

VI) Hurry Inlet biotite granite. This is the most extensive of the Liverpool Land plutons.

VII) Biotite granite east of Klitdal.

The relative ages of groups II, III and IV are uncertain but they are assumed to post-date I, and to be older than group V. The groups VI and VII are the youngest.

These various intrusions are considered to form a series in the sense of Read (1949). Read's concept that depth of crystallisation controlled the relations between a granite and its host has now been superseded or modified and the temperature difference between granitic mass and host is considered to be crucial. This indicates a time range for members of a series. At the time of writing, only one radiometrically determined date is available for the granite series, and this $(434 \pm 10 \mathrm{~m} . \mathrm{y}$.) is for the Hurry Inlet granite which is clearly a post-tectonic mass. For the granitic rocks to form a true series and to be genetically related the earliest which possibly are synkinematic should yield ages still related to a Caledonian deformation. From the arguments presented above for the antiquity of the gneiss series, it follows that either the granites are not all members of a series, or else the tectonic events to which the early members are related are not part of the deformation which produced the gneisses and related metamorphic rocks. The question is at present open, but evidence probably favours the view that an early tectonic event which gave rise to the gneiss complexes was followed by a Caledonian deformation and reactivation which gave rise to the granitic plutonic rocks. 
The petrography of these granites is very briefly summarised below.

I) The Age Nielsen Gletscher granodiorite. This is highly variable in mineral composition as well as in texture and structure. Field relations show gradational contacts with gneissic host rocks and heavily migmatised patches occur within the mass. The colour index ranges from 5 to 25 and ratios of the three leucocratic components extend through the following range:

$\begin{array}{ccc}\begin{array}{c}\text { K feldspar } \\ (\%)\end{array} & \begin{array}{c}\text { Plagioclase } \\ (\%)\end{array} & \begin{array}{c}\text { Quartz } \\ (\%)\end{array} \\ 65 & 17 & 18 \\ 20 & 50 & 30 \\ 25 & 50 & 25 \\ 30 & 60 & 10\end{array}$

Biotite and hornblende are the most abundant ferromagnesian minerals, with augite appearing in some samples. Sphene is a common accessory. The texture is variable but mostly the rock is coarse-grained and in most slides examined there is a strong development of myrmekite.

II) The big feldspar granite at Kap Jones. This rock is characterised by the presence locally of potash feldspar crystals up to $50 \mathrm{~mm}$ in length. The distribution of these is variable. The matrix is medium-grained granite or granodioritic in composition and relatively leucocratic with a colour index of 10 to 20 .

III) Sandbach Halvø quartz monzonite and related rocks from east of Klitdal. These rocks range in the colour index from very low to about 20 . The main ferromagnesian constituents are hornblende and biotite but pyroxene is usually present in the core of the hornblende crystals. The felsics vary so that the rocks range from a quartz diorite to quartz monzonite. The texture is homogeneous, granular and medium-grained.

IV) Hodal-Storefjord quartz monzodiorite. This appears relatively homogeneous in the field. It is medium-grained and sometimes slightly foliated. Its relations with host rocks are poorly displayed except in the south, where a sheeted contact, sometimes faulted, is found against gneiss. The colour index ranges from 20 to 30 , the principal ferromagnesian mineral being hornblende, but both pyroxene and biotite also occur together with chlorite and epidote as alteration products. The felsics fall within the following limits:

$\begin{array}{ccc}\begin{array}{c}\text { K feldspar } \\ (\%)\end{array} & \begin{array}{c}\text { Plagioclase } \\ (\%)\end{array} & \begin{array}{c}\text { Quartz } \\ (\% / 0)\end{array} \\ 5 & 90 & 5 \\ 30 & 56 & 15\end{array}$


V) The hornblende-biotite granite of Storefjord. This is a somewhat variable granitic rock, often porphyritic in texture with both potash feldspar and plagioclase in large crystals. The rock ranges from quartz monzodiorite to true granite and the colour index from 12 to 24 . Biotite is the principal ferromagnesian mineral, with hornblende associated.

VI) The Hurry Inlet biotite granite. Four main facies of this mass have been recognised but all are granodioritic or granitic. In places perthite megacrysts are abundant, whilst in others the rock is medium grained and granular. Aplitic leucocratic facies and more melanocratic facies are probably the results of contamination. Xenoliths are very abundant especially in the border zones. Contacts with host rocks are sharp and in places faulted. Modal analyses show a relatively small range in ratios of the felsic constituents and the samples are grouped on the granite/granodiorite boundary.

VII) Biotite granite east of Klitdal. This is a relatively homogeneous mass, leucocratic with a colour index not more than 15 . The texture, like that of the Hurry Inlet granite, varies from granular (fine- to medium-grained) to porphyritic. The composition is of a quartz monzonite or granite. Potash feldspar reaches $70 \%$ of the total in some facies. Biotite is the only prominent dark mineral and this may be completely replaced by chlorite.

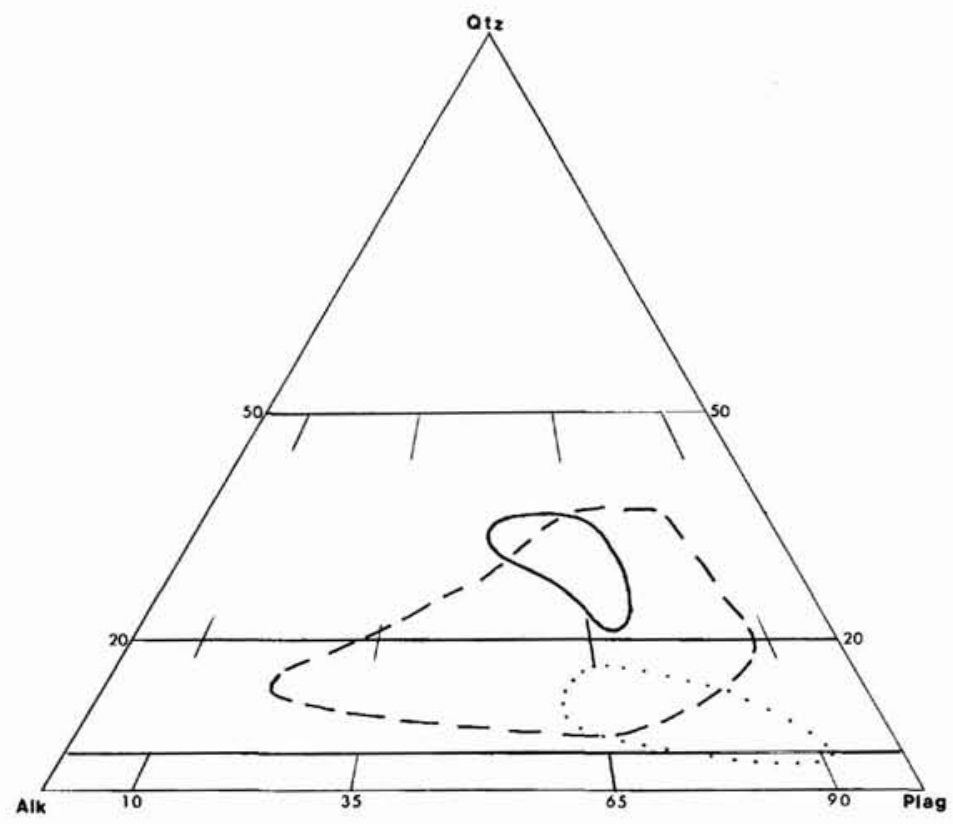

Fig. 2. Plots of modal quartz, potash feldspar and plagioclase to show range in composition of some of the plutonic rocks. Full line: Hurry Inlet biotite granite: dashed line: Åge Nielsen Gletscher granodiorite; dotted line: Hodal-Storefjord quartz monzodiorite 
The diagram (fig. 2) shows the range in composition of the Åge Nielsen Gletscher granodiorite compared with that of the Hurry Inlet biotite granite and the HodalStorefjord quartz monzodiorite represented by plots of modal quartz, potash feldspar and plagioclase on the diagram proposed by Streckeisen (1967).

All the granite masses have associated aplite, pegmatite or microgranite sheets in varying attitudes and abundance. Fuller descriptions with comments on the significance of the sheets will appear in later reports.

\section{Non-metamorphosed rocks}

\section{Upper Palaeozoic sedimentary rocks}

Rocks included in this category are distinguished by being unmetamorphosed. They are all clastic, mostly coarse grained and in most cases clearly of local derivation. They can be divided on lithological grounds into two groups:

$\begin{array}{ll}\text { Sandstones, siltstones } & \text { upper } \\ \text { Conglomerates } & \text { lower }\end{array}$

They are overlain by marls and sandstones, presumed to be of Mesozoic age, with marked unconformity. A fault always separates the lower from the upper group. It is clear that the conglomerates are the older, yet they dip at a lower angle (to the west) than the beds of the upper group. The significance of this and relations with overlying sediments have been discussed elsewhere (Coe, 1971).

The conglomerate lies on a planed surface of the Hurry Inlet granite with a gentle dip to the west. To the north, south and west the outcrop of the conglomerate is limited by vertical faulting. In places there is evidence that it was deposited in a fault-bounded trough and the present boundary faults may be zones along which there has been renewed movement. The bedding of the rock is massive and it is composed of boulders, cobbles, pebbles and grains mostly of Hurry Inlet granite. This material is usually fresh so that the secondary rock closely resembles its parent. This is particularly the case when it is compared with the granite from fault zones.

Whereas the conglomerates are uniform in character, the succeeding group is highly variable, consisting of sandstones, some of which are very coarse-grained, siltstones and mudstones. Some of the bands are calcareous. The group is characterised by rapid variation both within and across the strike, so that precise correlation is not possible. Fine sandstone and grits alternate in the lower part of the succession. Above these are coarser sandstones and bedded conglomerates, in which feldspars and granite pebbles are abundant. The sequence is always well bedded, often cross-bedded and sometimes shows other sedimentary structures. This part of the succession is exposed in the Damelv section, a sequence of 
outcrops described by Bütler (1957). Coast exposures, usually very clean, vary from small outcrops protruding through beach deposits to extensive rocky headlands. Arkosic conglomerates which make up the greater part of the succession contain an abundance of pink feldspars. There are usually more or less isolated granite pebbles often bigger than $0.1 \mathrm{~m}$ in diameter, and these frequently are rounded. Cross-bedding is common. Interbedded with the conglomerates are flagstones and shales in which ripple drift is prominent. Plant fragments commonly occur in the shale horizons.

Throughout these coastal localities the dip is to the west at a high angle and at the southern extremity of outcrop the beds are either overturned or vertical, but all are west facing and the exaggerated dips are due to proximity to the boundary fault.

\section{Mesozoic rocks}

Triassic sandstones crop out on the small islands at the head of Hurry Inlet (Coe, 1971) and north of there in Klitdal. In the more northerly area, a marked unconformity can be seen between them and the crystalline rocks. The surface dips regularly and gently to the west. The rocks above the unconformity are red sandstones and arkose and these are overlain by more pelitic grey lithologies. The unconformity surface is deeply weathered and in places the zone of weathering is up to $1.5 \mathrm{~m}$ deep and has resulted in discolouration, disintegration and exfoliation of the crystalline rocks.

A small poorly exposed area north-east of Kap Hope is considered to be of Triassic-Jurassic rocks (Rosenkrantz, 1942).

\section{Minor intrusions}

A series of minor basic intrusions, assumed to be Tertiary in age, penetrates the Hurry Inlet granite and overlying sedimentary rocks. Three petrographic types have been distinguished, viz. dolerites, lamprophyres and feldsparphyric basalts. Lamprophyres and the feldsparphyric basalts have been seen cutting the sedimentary rocks and some individuals cross the faulted boundary between granite and sediment. No dolerites have been observed in the sedimentary rocks, but firm conclusions on the relative ages cannot be drawn from this negative evidence as the dolerites are few in number especially in the western part of the area.

Relating to similar rocks outside the area, a Tertiary age has been assumed for all these minor intrusions, and there is no justification for doubting this assumption. The porphyries are distinctive rocks and apparently similar to sills intruded into Mesozoic strata in Jameson Land (Surlyk \& Birkelund, this report), indicating a 
late Mesozoic or Tertiary age. No dyke intersections have been observed so that it has not been possible to establish a chronology within the suite. The dykes are abundant in the granites and gneisses west of the central watershed. The lamprophyres, especially, seem to be geographically related to the Hurry Inlet granite even though they are removed in time by the period of unroofing of the granite. However, such a time gap has been noted in other areas where granite plutons and lamprophyres are related. Here, however, it seems that the lamprophyres are part of a regionally developed swarm, members of which have been described from distant parts of the east coast of Greenland (Vincent, 1953; Wager \& Deer, 1938; Bearth, 1959). Their spatial association with the granite thus appears to be structural and not genetic.

Like the lamprophyres, the dolerites are near north-south in trend. They vary from deeply altered vesicular sheets to hard, black, fresh bodies. Towards the east coast they become fewer, but those occurring are more persistent and can be traced for distances of up to $9 \mathrm{~km}$. The feldsparphyric basalts are confined to a sill around the head of Hurry Inlet.

\section{References}

Bearth, P. 1959: On the alkali massif of the Werner Bjerge in East Greenland. Meddr Grønland $153,4,63 \mathrm{pp}$.

Bütler, H. 1957: Beobachtungen an der Hauptbruckzone der Küste von Zentral-Ost-Grönland. Meddr Gronland 160, 1, 79 pp.

Coe, K. 1971: Faulting in the west part of Liverpool Land, East Greenland. Bull. geol. Soc. Denmark 20, 260-264.

Hansen, B. T. \& Steiger, R. H. 1971: The geochronology of the Scoresby Sund area. Progress report I: Rb/Sr mineral ages. Rapp. Gronlands geol. Unders. 37, 55-57.

Henriksen, N. \& Higgins, A. K. 1969: Preliminary results of mapping in the crystalline complex around Nordvestfjord, Scoresby Sund, East Greenland. Rapp. Gronlands geol. Unders. 21, 5-20.

Kleiber, K. 1944: Beitrag zur Geologie und Sedimentpetrographie Ostgrönlands. Meddr Gronland $115,4,148 \mathrm{pp}$.

Kranck, E. H. 1935: On the crystalline complex of Liverpool Land. Meddr Gronland 95, 7, 122 pp.

Nathorst, A. G. 1901: Bidrag till nordöstra Grönlands geologi. Geol. Fören. Stockh. Förh. 23, 275-306.

Nordenskjöld, O. 1907: On the geology and physical geography of East-Greenland. Meddr Gronland 28, 5, 151-284.

Read, H. H. 1949: A contemplation of time in plutonism. Q. $l l$ geol. Soc. Lond. 105, 101-156.

Rosenkrantz, A. 1942: The lower Jurassic Rocks of East Greenland. Part II. The Mesozoic sediments of the Kap Hope area southern Liverpool Land. Meddr Gronland 110, 2, $56 \mathrm{pp}$.

Sahlstein, Th. G. 1935: Petrographie der Eklogiteinschlusse in den Gneisen des südwestlichen Liverpool-Landes in Ost-Grönland. Meddr Gronlanci 95, 5, 43 pp.

Streckeisen, A. 1967: Classification and nomenclature of igneous rocks. Neues Jb. Miner. Abh. 107, 144-240. 
Vincent, E. A. 1953: Hornblende-lamprophyre dykes of basaltic parentage from the Skaergaard area, East Greenland. Q. $J l$ geol. Soc. Lond. 109, 21-50.

Wager, L. R. \& Deer, W. A. 1938: A dyke swarm and crustal flexure in East Greenland. Geol. Mag. 75, 39-46. 